\section{Effect of Two Microshear Test Devices on Bond Strength and Fracture Pattern in Primary Teeth}

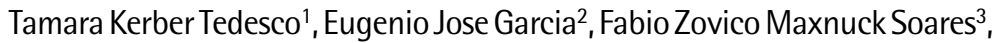
Rachel de Oliveira Rocha', Rosa Helena Miranda Grande²

This in vitro study evaluated the influence of two devices for application of shear load in microshear tests on bond strength and fracture pattern of primary enamel and dentin. Eighty primary molars were selected and flat enamel (40 teeth sectioned mesio-distally) and dentin (40 teeth sectioned transversally) surfaces were obtained. Both surfaces were polished to standardize the smear layer. Two-step etch-and-rinse adhesive systems (Adper Single Bond and XP Bond) were used. Polyethylene tubes was placed over the bonded surfaces and filled with composite resin. The microshear testing was performed after storage in water $\left(24 \mathrm{~h} / 37^{\circ} \mathrm{C}\right)$ using two devices for application of microshear loads: a notched rod (Bisco Shear Bond Tester) or a knife edge (Kratos Industrial Equipment). Failure modes were evaluated using a stereomicroscope. Bond strength data were subjected to ANOVA and chi-square test to compare the failure mode distributions $(\alpha=0.05)$. No significant differences were observed between the groups for dentin and enamel bond strength or fracture patterns $(p>0.05)$. The predominant failure mode was adhesive/mixed. In conclusion, the devices for application of shear loads did not influence the bond strength values, regardless of adhesive system and substrate.

\author{
'Department of Stomatology, \\ UFSM - Federal University of Santa \\ Maria, Santa Maria, RS, Brazil \\ ${ }^{2}$ Department of Biomaterials and \\ Oral Biology, USP - University of \\ São Paulo, São Paulo, SP, Brazil \\ ${ }^{3}$ Department of Restorative Dentistry, \\ UFSM - Federal University of Santa \\ Maria, Santa Maria, RS, Brazil
}

Correspondence: Dra. Rachel de Oliveira Rocha, Rua Floriano Peixoto, 1184, 97015-372 Santa Maria, RS, Brasil. Tel: +55-55-3220-9291. email: rachelrocha@smail.ufsm.br

Key Words: enamel, dentin, adhesive system, microshear bond strength, primary tooth.

\section{Introduction}

Recent developments of dental adhesives led several researchers to evaluate the early performance of new materials on dental substrates. The determination of the clinical success of these materials is primordial; however, their efficacy should first be tested in laboratory.

Bond strength tests are simple and effective methods for evaluation of adhesive systems. In order to improve the accuracy of bond strength evaluation, Sano et al. (1) proposed the microtensile bond testing ( $\mu$ TBS). This test has been widely used $(2,3)$; nevertheless, there are reports in the literature that this is not an easy method to be applied in enamel due to its brittleness and the stresses generated during specimen preparation that can lead to fracture of enamel-resin interface (4).

More recently, the microshear bond testing ( $\mu \mathrm{SBS})$ was introduced as an alternative to the $\mu$ TBS test (5). However, the studies showed a lack of standardization among researchers regarding several parameters related to this test, resulting in considerable discrepancies of bonding data on the same adhesive system in different studies $(6,7)$ or even within the same research center $(7,8)$.

Several parameters of $\mu$ TBS test have been addressed by previous studies. The influence of cross-section shape and surface area (9), cutting speed (10) and geometry of the specimens, as well as the mode of fixation and the devices used for testing (11) are some of the factors.
On the other hand, for the $\mu$ SBS test, few studies have attempted to evaluate and standardize the variables of this test $(12,13)$, which can also influence the results. In the same manner, most studies that evaluated the bond strength of adhesive systems using the $\mu \mathrm{SBS}$ test were performed on permanent teeth (5-8). Therefore, there is little or no information about how this test applies to primary teeth (14-16).

The aim of this current in vitro study was to evaluate the influence of two devices for application of microshear load in bond strength and fracture pattern to enamel and dentin of primary teeth. The null hypothesis was that both loading devices do not influence the $\mu$ SBS values and fracture pattern of two-step etch-and-rinse adhesives applied to primary enamel and dentin.

\section{Material and Methods}

After approval of the Ethics Committee of the University of São Paulo (Protocol \#179/2010), 80 caries-free primary second molars, exfoliated or extracted for orthodontics reasons, were used in this study. The teeth were cleaned and stored in a $0.5 \%$ chloramine-T solution at $4{ }^{\circ} \mathrm{C}$ for 7 days. Then the teeth were stored in distilled water at the same temperature until use for up to 6 months.

The teeth were randomly assigned to 8 groups $(n=10)$ based on: adhesive system - Adper Single Bond 2 - SB2 (3M ESPE, St. Paul, MN, USA) or XP Bond - XPB (Dentsply De Trey, Konstanz, Germany); load test device - knife edge (Kratos 
Equipamentos Industriais, Cotia, SP, Brazil) or notched rod (Bisco Shear Bond Tester; Bisco, Schaumburg, IL, USA); and dental substrate - enamel or dentin. The composition and manufacturers' instructions of the adhesive systems are summarized in Table 1.

\section{Preparation of Enamel Specimens}

The crowns of 40 teeth were sectioned mesio-distally using a low speed water-cooled diamond saw in a precision cutting machine (Labcut 1010; Extec Co, Enfield, CT, USA) to obtain eighty enamel sections. The sections were embedded in PVC rings using self-curing acrylic resin (JET Clássico, São Paulo, SP, Brazil). The enamel surfaces of mid-coronal regions were ground under water-cooling with 320-grit $\mathrm{SiC}$ paper in order to obtain flat surfaces, and further polished with 600-grit SiC paper for $60 \mathrm{~s}$ to standardize the smear layer.

\section{Preparation of Dentin Specimens}

The other 40 teeth were attached to a PVC ring previously filled with self-curing acrylic resin, using sticky wax in order to obtain forty flat dentin discs by transversal cuts using a low speed diamond saw under water-cooling $\vec{s}$ in the cutting machine. Discs were included in plastic tubes and dentin surfaces were then polished to obtain a standardized smear layer.

\section{Bonding and Restorative Procedures}

The adhesive systems were applied on the sections of enamel and dentin surfaces following the manufacturer's instructions (Table 1). After light-activation, polyethylene tubes (internal diameter of $0.76 \mathrm{~mm}$ and $1.0 \mathrm{~mm}$ height) (Micro-bore ${ }^{\circledR}$ Tygon S-54-HL Medical Tubing; Saint-Gobain Performance Plastics, Akron, $\mathrm{OH}, \mathrm{USA}$ ) were placed on these bonded areas. In each enamel and dentin section were placed two and four Tygon tubes, respectively. All tubes were filled up with composite resin (Filtek Z250; 3M ESPE), covered with a matrix strip, gently pressed with a glass slide, and light activated. In all cases, light activation was performed using a quartz-tungsten halogen-light unit at $500 \mathrm{~mW} / \mathrm{cm}^{2}$ (Optilux 501; Kerr Corp, Orange, CA, USA). All bonding and restorative procedures were carried out by a single operator at a room temperature of $24^{\circ} \mathrm{C}$.

After storage in distilled water at $37^{\circ} \mathrm{C}$ for $24 \mathrm{~h}$, excess composite resin or adhesive systems were gently removed using a scalpel blade. In the same way, Tygon tube was removed resulting in 2 and 4 specimens (cylinders of resin composite with cross-sectional area of $0.45 \mathrm{~mm}^{2}$ ) for section of the enamel and dentin, respectively. The specimens were examined under a stereomicroscope at 10x magnification and those with interfacial gaps, trapped bubbles or other defects were discarded and replaced.

The specimens were arranged in the mounting jigs of the testing machines. The loading devices (Bisco Shear Bond Tester: notched rod; Kratos: knife edge) (Fig. 1) were placed to make contact with the bonded specimen at the composite and enamel/dentin interface warranting the application of a force parallel to the bonded surface.

The composite resin specimens were randomly subjected to tests in both shearing machines. Shear load was applied at a crosshead speed of $1.0 \mathrm{~mm} / \mathrm{min}$ until failure of the specimen occurred.

\section{Failure Mode}

Failure modes were evaluated by a single operator under a stereomicroscope (Stereo Discovery V20; Carl Zeiss Ltda., Rio de Janeiro, RJ, Brazil) at 200× magnification, and classified as: adhesive-mixed failure (presence of dentin, enamel or resin adjacent to interface) or cohesive (failure in enamel/dentin/composite resin).

Table 1. Adhesive systems; manufacturers, compositions and manufacturers' instructions

\begin{tabular}{|c|c|c|}
\hline Material (Manufacturer) & Composition & Manufacturers' instruction for use \\
\hline $\begin{array}{l}\text { Adper Single Bond } 2 \\
\text { (3M/ESPE, St. Paul, } \\
\text { MN, USA) }\end{array}$ & $\begin{array}{l}\text { Bis-GMA, HEMA, ethanol, water, dimethacrylate, } \\
\text { amines, methacrylic, copolymer of polyacrylic } \\
\text { and poly(itaconic acid) acids, and photo-initiator }\end{array}$ & $\begin{array}{l}\text {-Etch with phosphoric acid gel for } 15 \mathrm{~s} \text { then rinse for } 30 \mathrm{~s} \\
\text { - Blot excess water with cotton pellet } \\
\text { - Apply two coats of bond with rubbing motion for } 15 \mathrm{~s} \\
\text { - Air-thin for } 5 \mathrm{~s} \\
\text { - Light cure for } 10 \mathrm{~s}\end{array}$ \\
\hline $\begin{array}{l}\text { XP Bond } \\
\text { (Dentsply De Trey, } \\
\text { Konstanz, Germany) }\end{array}$ & $\begin{array}{l}\text { Carboxylic acid modified dimethacrylate, } \\
\text { camphorquinone, HEMA, TEGDMA, PENTA, UDMA, } \\
\text { butylated benzenediol, Ethyl-4-dimethylaminobenzoate, } \\
\text { functional amorphous silica, t-butanol. }\end{array}$ & $\begin{array}{c}\text {-Etch with phosphoric acid gel for } 15 \mathrm{~s} \text { then rinse for } 30 \mathrm{~s} \\
\text { - Blot excess water with cotton pellet } \\
\text { - Apply two coats of bond and leave for } 20 \mathrm{~s} \\
\text { - Air-blow for } 5 \mathrm{~s} \\
\text { - Light cure for } 10 \mathrm{~s}\end{array}$ \\
\hline
\end{tabular}

HEMA: 2-hydroxyethyl methacrylate; Bis-GMA: bisphenol A diglycidyl methacrylate; TEGDMA: Triethylene glycol dimethacrylate; PENTA: dipentaerythritol pentaacrylate monophosphate; UDMA: urethane dimethacrylate. 


\section{Statistical Analysis}

Bond strength means values were expressed in MPa. Microshear bond strength data were tested for normal distribution using a Kolmogorov-Smirnov test. Data from enamel and dentin were subject to 2-way ANOVA to examine the influence of adhesive systems and shear load devices, and chi-square test was used to compare the fracture modes. The significance level was set at $p \leq 0.05$.

\section{Results}

Mean shear bond strength values (in MPa) and standard deviations for the groups of dentin and enamel are shown in Table 2.

ANOVA showed that there was no significant difference between the adhesive systems $(p=0.0972 ; p=0.1078)$, shear test devices $(p=0.3771 ; p=0.3640)$ and for the interaction between the two factors $(p=0.2007 ; p=0.1145)$, for dentin and enamel, respectively.

Chi-square analysis showed no significant difference in the fracture patterns between groups [dentin ( $p=0.668)$ and enamel $(p=0.737)]$. Adhesive-mixed failures were most

Table 2. Mean bond strength values and standard deviations (in MPa) for each group

\begin{tabular}{lccccc}
\hline \multirow{2}{*}{$\begin{array}{l}\text { Adhesive } \\
\text { system }\end{array}$} & \multicolumn{2}{c}{ Dentin } & & \multicolumn{2}{c}{ Enamel } \\
\cline { 2 - 3 } \cline { 5 - 6 } & $\begin{array}{c}\text { Knife } \\
\text { edge }\end{array}$ & $\begin{array}{c}\text { Notched } \\
\text { rod }\end{array}$ & & $\begin{array}{c}\text { Knife } \\
\text { edge }\end{array}$ & $\begin{array}{c}\text { Notched } \\
\text { rod }\end{array}$ \\
\hline $\begin{array}{l}\text { Adper Single } \\
\text { Bond 2 }\end{array}$ & $27.5 \pm 5.8$ & $27 \pm 4.9$ & & $28.4 \pm 6.7$ & $24.5 \pm 6.4$ \\
XP Bond & $26.3 \pm 5.2$ & $26.3 \pm 5.1$ & & $24 \pm 7.1$ & $25.4 \pm 6.4$ \\
\hline
\end{tabular}

frequently identified in all groups. There were no cohesive enamel or dentin failures.

Figures 2 and 3 show the prevalence of fractures observed for each experimental group.

\section{Discussion}

The current study identified the lack of influence of both

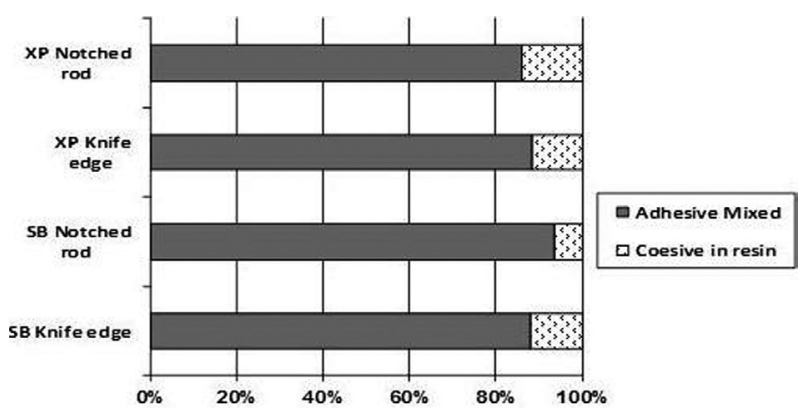

Figure 2. Failure modes (percent) for experimental groups in dentin.

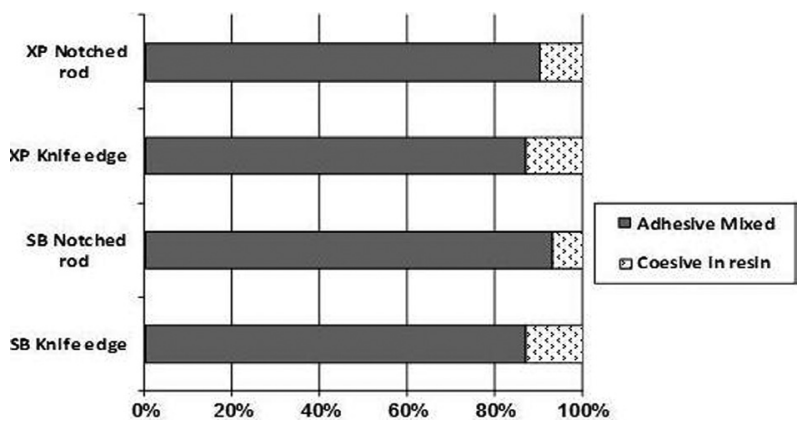

Figure 3. Failure modes (percent) for experimental groups in enamel.
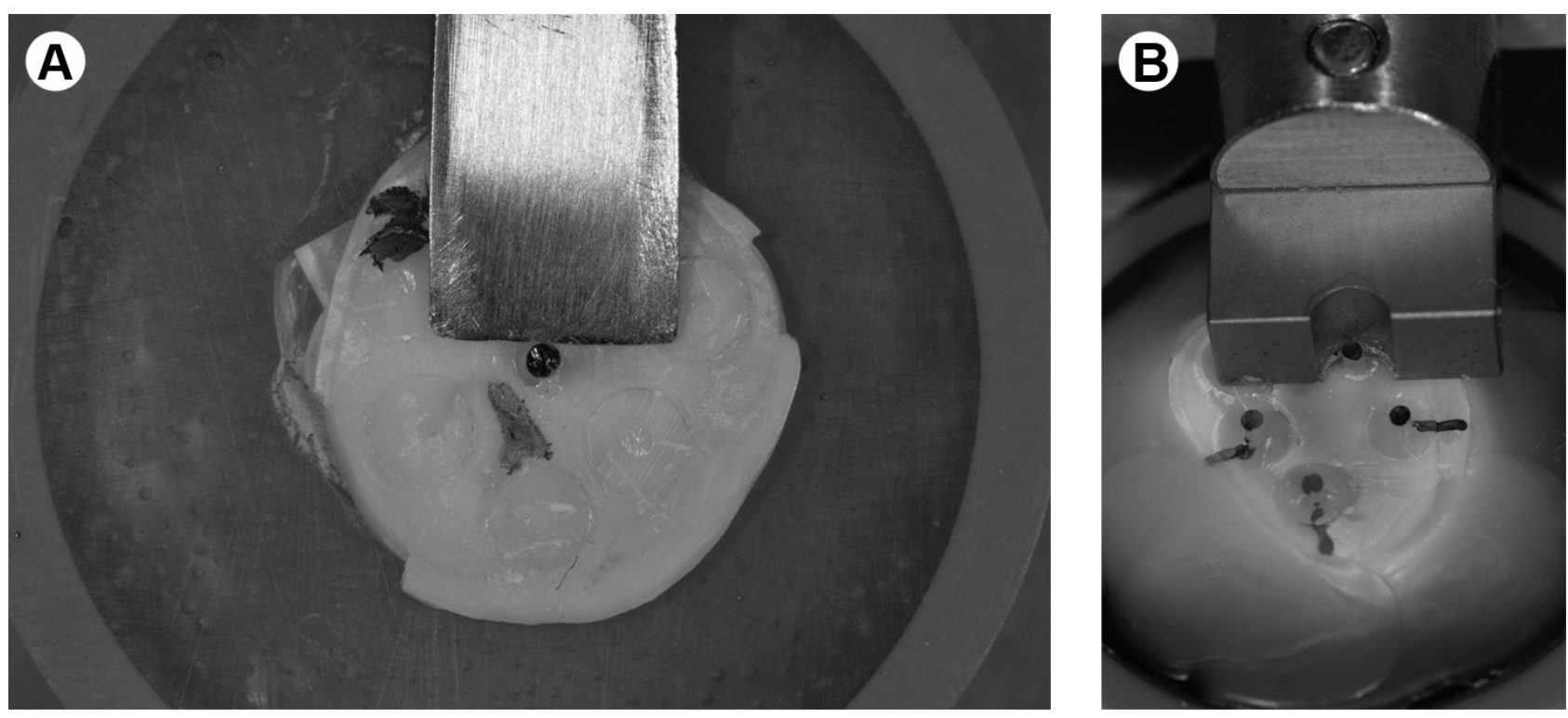

Figure 1. Loading devices. A: Knife-edge. B: Notched rod. 
devices used for application of shear forces on microshear bond strength testing. No significant differences in mean bond strength values were observed between the testing machines. So, the null hypothesis could not be rejected.

Higher shear bond strength values are expected when the shear device applied load forces on larger contact areas such as with the wire loop (4), stainless steel tape (17) and the Ultradent device (18), due to a more even distribution of shear forces. In this way, some issues such as specimen size (19), loading length (5), adhesive layer thickness (20), loading site (18) have been reported to affect the stress distribution and concentration, the direction of forces and, ultimately the bond strength values, coefficients of variation, and failure modes. However, to the best of our knowledge, this is the first study that compared different devices to apply shear load, notched rod and knife edge, especially evaluating the performance of the adhesive systems on primary teeth. The diameter of the notched rod is $2.36 \mathrm{~mm}$ and the contact height is $0.38 \mathrm{~mm}$ from the surface of the sample. The total overall height of the test blade is $3.96 \mathrm{~mm}$, but the diameter is recessed so only the very bottom is under stress; thus, considering the diameter of the composite cylinders, the notched rod seems to apply the shear forces in a small contact area, in the same way as a knife edge.

Studies based on finite element analyses observed that, although the use of wire-loop rather than knife edge seems to reduce the stress concentration magnitude adjacent to the adhesive interface, this method results in grossly underestimated bond strength values (21). In this sense, even though many studies still use the wire-loop to apply the shear load, this shows the importance of evaluating the other devices.

One of the most critical factors on microshear testing is that the shear load must be applied precisely at bonded interface to avoid that the composite cylinder is subjected to rotation or bending rather than a shear tension (4). In this study the two devices were carefully positioned as close as possible to the adhesive interfaces. This assured that loading forces were applied on resin-substrate interface, observing the absence of interferences during the tests.

Foong et al. (4) found greater standard deviations and coefficients of variation using a blade instead of wire loop devices. According to these authors, it seems that there was some difficulty to reproduce the same position of the blade for all specimens. However, in the current study there was no difficulty to apply the shear forces using both devices. This shows that the device positioning is an important factor in shear stresses, rather than the type of device.

The fracture analysis showed a predominance of adhesive/mixed fractures in enamel and dentin, and no difference between the testing devices, corroborating the findings of previous studies $(4,18)$. As usually observed for $\mu$ SBS tests, there were few cohesive fractures $(4,7,8)$. This may be ascribed to the fact that the load was correctly applied, leading to more consistent results than those found for $\mu$ TBS test. Microtensile testing requires more cutting and trimming during the preparation of the specimens, which could result in cracks and defects on enamel due to its high elastic modulus and brittleness (4).

The results of the present study are of much importance because of the lack of studies assessing $\mu$ SBS in primary teeth and there always remained doubts about the adhesive behavior of these teeth. The thicker aprismatic enamel layer, lower density and diameter of dentinal tubules and lower phosphate and calcium concentration in the peritubular and intertubular dentin (17) are some of the factors that explain the lower bond strength values of primary teeth, confirming that the results of bond strength testing for permanent teeth cannot be directly extrapolated to primary teeth.

Additionally, the current study found similar results for the two adhesive systems both for enamel and dentin, probably due to their composition and etching approach, and not to the device used for microshear bond strength tests. Previous studies showed that SB2 presented a good performance on dentin and enamel $(22,23)$. In the same manner, $X P B$, a recently formulated two step etch-and-rinse adhesive system, presented performance similar to SB2 in both substrates, corroborating earlier studies $(23,24)$. XPB is claimed to be less technique-sensitive due to an improved ability to diffuse through partially collapsed demineralized dentin, showing complete infiltration of demineralized dentin by the resin monomers facilitated by the tertiary butanol used as a solvent and a chemical interaction with demineralized dentin (25). Further studies should be carried out to confirm the lack of influence of both devices in ranking different bonding approaches.

Within the limitations of this study, it may be concluded that neither of the two devices used for applying shear load influenced the bond strength in enamel and dentin, regardless of the adhesive system.

\section{Resumo}

Este estudo in vitro avaliou a influência de dois dispositivos para aplicação de força de cisalhamento em testes de resistência de união ao microcisalhamento e no padrão de fratura em dentina e esmalte de dentes deciduos. Oitenta molares deciduos foram selecionados e superficies planas em esmalte (40 dentes seccionados no sentido mésio-distal) e dentina (40 dentes seccionados transversalmente) foram obtidas. Ambas as superficies foram abrasionadas para padronização da lama dentinária. Dois sistemas adesivos de condicionamento ácido prévio (Adper Single Bond e XP Bond) foram utilizados. Tubos de polietileno foram colocados sobre as superficies, nas quais já haviam sido aplicados os sistemas adesivos, e preenchidos com resina composta. 0 teste de resistência de união ao microcisalhamento foi realizado após armazenamento dos espécimes em água $\left(24 \mathrm{~h} / 37{ }^{\circ} \mathrm{C}\right)$ utilizando dois dispositivos para a aplicação das forças de cisalhamento: 
cisalha côncava (Bisco Shear Bond Tester) e cisalha plana (Kratos Industrial Equipment). 0 padrão de fratura foi avaliado usando estereomicroscópio. Os dados de resistência de união foram submetidos à ANOVA e o teste quiquadrado foi utilizado para comparar a distribuição dos padrões de fratura $(\alpha=0,05)$. Não foram observadas diferenças estatisticamente significantes entre os grupos, tanto para a resistência de união a dentina e esmalte quanto para o padrão de fratura $(p>0,05)$. 0 modo de falha predominante foi adesiva/mista. Em conclusão, os dispositivos para aplicação de força de cisalhamento não influenciam os valores de resistência de união, independente do sistema adesivo e substrato.

\section{References}

1. Sano $H$, Shono $T$, Sonoda $H$, Takatsu $T$, Ciucchi B, Carvalho $R$, et al.. Relationship between surface area for adhesion and tensile bond strength-evaluation of a microtensile bond test. Dent Mater 1994;10:236-240.

2. Lenzi TL, Tedesco TK, Soares $F Z$, Loguercio $A D$, Rocha $R$ de 0 . Chlorhexidine does not increase immediate bond strength of etchand-rinse adhesive to caries-affected dentin of primary and permanent teeth. Braz Dent J 2012;23:438-442.

3. Hipólito VD, Alonso RC, Carrilho MR, Anauate Netto C, Sinhoreti MA, Goes MF. Microtensile bond strength test and failure analysis to assess bonding characteristics of different adhesion approaches to ground versus unground enamel. Braz Dent J 2011;22:122-128.

4. Foong J, Lee K, Nguyen C, Tang G, Austin D, Ch'ng C, et al.. Comparison of microshear bond strengths of four self-etching bonding systems to enamel using two test methods. Austr Dent J 2006;51:252-257.

5. McDonough WG, Antonucci JM, He J, Shimada Y, Chiang MY, Schumacher $\mathrm{GE}$, et al.. A microshear test to measure bond strengths of dentin-polymer interfaces. Biomaterials 2002;23:3603-3608.

6. Li N, Nikaido T, Takagaki T, Sadr A, Makishi P, Chen J, et al.. The role of functional monomers in bonding to enamel: acid-base resistant zone and bonding performance. J Dent 2010;38:722-730.

7. Wang H, Shimada Y, Tagami J. Effect of fluoride in phosphate buffer solution on bonding to artificially carious enamel. Dent Mater J 2007;26:722-727.

8. Shida K, Kitasako Y, Burrow MF, Tagami J. Micro-shear bond strengths and etching efficacy of a two-step self-etching adhesive system to fluorosed and non-fluorosed enamel. Eur J Oral Sci 2009;117:182-186.

9. Phrukkanon S, Burrow MF, Tyas MJ. The influence of cross-sectional shape and surface area on the microtensile bond test. Dent Mater 1998;14:212-221.

10. Abreu CW, Santos JFF, Passos SP, Michida SM, Takahashi FE, Bottino $M A$. The influence of cutting speed and cutting initiation location in specimen preparation for the microtensile bond strength test. J Adhes Dent 2011;13:221-226.

11. Raposo LH, Armstrong SR, Maia RR, Qian F, Geraldeli S, Soares CJ. Effect of specimen gripping device, geometry and fixation method on microtensile bond strength, failure mode and stress distribution: laboratory and finite element analyses. Dent Mater 2012;28:50-62.

12. Andrade AM, Moura SK, Reis A, Loguercio AD, Garcia EJ, Grande RH. Evaluating resin-enamel bonds by microshear and microtensile bond strength tests: effects of composite resin. J Appl Oral Sci 2010;18:591598.

13. Andrade AM, Garcia E, Moura SK, Reis A, Loguercio A, Silva LM, et al.. Do the microshear test variables affect the bond strength values? Int J Dent 2012 [Epub ahead of Print. DOI: 10.1155/2012/618960].

14. Krifka S, Börzsönyi A, Koch A, Hiller KA, Schmalz G, Friedl KH. Bond strength of adhesive systems to dentin and enamel-Human vs. bovine primary teeth in vitro. Dent Mater 2008;24:888-894.

15. Knirsch MS, Bonifácio CC, Shimaoka AM, Andrade AP, Carvalho RCR. Bonding effectiveness of different adhesion approaches to unground versus ground primary tooth enamel. Eur J Paediatr Dent 2009;10:8389.

16. Leitune VC, Portella FF, Bohn PV, Collares FM, Samuel SM. Influence of chlorhexidine application on longitudinal adhesive bond strength in deciduous teeth. Braz Oral Res 2011;25:388-392.

17. Sinhoreti MA, Consani S, De Goes MF, Sobrinho LC, Knowles JC. Influence of loading types on the shear strength of the dentin-resin interface bonding. J Mater Sci Mater Med 2001;12:39-44.

18. Pecora N, Yaman P, Dennison J, Herrero A. Comparison of shear bond strength relative to two testing devices. J Prosthet Dent 2002;88:511515.

19. Placido E, Meira JB, Lima RG, Muench A, de Souza RM, Ballester RY. Shear versus micro-shear bond strength test: a finite element stress analysis. Dent Mater 2007;23:1086-1092.

20. Van Meerbeek B, Peumans M, Poitevin A, Mine A, Van Ende A, Neves A, et al.. Relationship between bond-strength tests and clinical outcomes. Dent Mater 2010;26:100-121.

21. DeHoff PH, Anusavice KJ, Wang Z. Three-dimensional finite element analysis of the shear bond strength. Dent Mater 1995;11:126-131.

22. Soares FZM, Rocha RO, Raggio DP, Sadek FT, Cardoso PEC. Microtensile bond strength of different adhesive systems to primary and permanent dentin. Pediatr Dent 2005;27:457-462.

23. Kimmes NS, Barkmeier WW, Erickson RL, Latta MA. Adhesive bond strengths to enamel and dentin using recommended and extended treatment times. Oper Dent 2010;35:112-119.

24. Frankenberger R, Lohbauer U, Roggendorf MJ, Naumann M, Taschner $M$. Selective enamel etching reconsidered: better than etch-and-rinse and self-etch? J Adhes Dent 2008;10:339-344.

25. Latta M. Shear bond strength and physicochemical interactions of XP Bond. J Adhes Dent 2007;9:245-248.

Received July 26, 2013 Accepted November 22, 2013 